\title{
RELATION BETWEEN TOXOCARA INFECTION, ATOPY AND ASTHMATIC BRONCHITIS CHILDREN IN ZAGAZIG UNIVERSITY HOSPITALS
}

\section{By}

MAHA S. BADAWEY ${ }^{1 *}$, GHADA M. FATHY ${ }^{1}$, SARA A. ABDEL-RAHMAN ${ }^{1}$, DALIA A. ABOLMAATY ${ }^{1}$ and BASHEER H. ABDALLAH ${ }^{2}$

Department of Parasitology ${ }^{1}$ and Department of Pediatrics ${ }^{2}$, Faculty of Medicine, Zagazig University, Zagazig, Egypt (*Correspondence: mahasaber2007@yahoo.com)

\begin{abstract}
This study evaluated the relation between toxocariasis and asthmatic bronchitis children in pediatric outpatient's clinics of Zagazig University Hospitals. The sample consisted of two groups; GI included 118 asthmatic bronchitis children recruited from outpatient's clinics. GII included 100 cross-matched healthy children selected randomly from the hospital visitors. All the children were subjected to full history taken as age, residence, socioeconomic level, pet animals, playing outdoors, and mother education chest examination. All participants were subjected to stool examination to exclude other parasites, oesinophilic count and detection of ELISA-IgG anti-Toxocara, skin prick test and total IgE for evaluation of atopy.

The results showed that $17 \%$ of asthmatic children were seropositive for anti-Toxocara spp., compared to $7 \%$ of the control ones. There was significant relation between positive antiToxocara IgG and asthmatic bronchitis as well as total IgE. On the other hand, there was negative significant relation between toxocariasis and skin prick test.
\end{abstract}

Key words: Toxocariasis, Pet animals, Children, Asthmatic bronchitis, ELISA-IgG, Total IgE

\section{Introduction}

Human toxocariasis (HT) is a cosmopoli$\tan$ zoonotic helminthic infection with (Toxocara canis and $T$. cati) the ascarid worms of dogs and cats respectively. There are other known species of Toxocara, but these are rarely or never infecting mans (Bowman and Hendrix, 2008). Toxocariasis was first detected in 1950s and considered as uncommon in children. Several researches detected that toxocariasis is the commonest worm worldwide (Hotez and Wilkins, 2009). Children are the most infected group as a reason of their common behaviors, like geophagia, bad personal hygienic condition and contact with animals that increase chance zoonotic transmission (Magnaval et al, 2001). Man is a paratenic host who get infected by accidental swallowing of the parasite's mature eggs found in feces of dog and/or cat indoors or outdoors (Despommier, 2003). Most of toxocariasis in man are asymptomatic (covert toxocariasis). However, symptomatic one gives three clinical features: visceral larva migrans (VLM), ocular larva migrans (OLM), and neurological toxocariasis (NT) (Fragoso et al, 2011). The pulmo- nary manifestation of toxocariasis is called covert. It is characterized by non-specific symptoms that are not related to the categories of classical VLM, incomplete larva migrans, OLM or NT. The clinical presentation of covert toxocariasis varies widely, with pulmonary involvement, such as asthma, acute bronchitis and pneumonia, with or without Loffler's syndrome. The diagnosis of asthma or a wheezing breath in toxocariasis patients was reported (Buijs et al, 1995). Frequency of both symptoms varied from $9 \%$ to more than $30 \%$ of adult patients (Carvalho and Rocha, 2011). These presentations were not so specific to Toxocara species but other helminthes larval stages may wander in human body causing symptoms of visceral larva migrans (Gavignet et al, 2008). The infection morbidity depends on parasite burden and host immune response (Macpherson, 2013). Asymptomatic human toxocariasis might be presented with impaired cognitive functions (Walsh and Haseeb, 2012) and immunomodulation (Maizels, 2013). The pulmonary toxocariasis was with asthmalike symptoms (Cooper, 2008).

In general, human helminthiasis has mark- 
ed role in the regulation of allergy in the tropics (Maizels, 2013). Trichuris trichiura (Moncayo et al, 2010), Schistosoma mansoni (Araujo et al, 2000) and Ascaris lumbricoides (Dagoye et al, 2003) were associated with a decrease in incidence of skin test reactivity and asthma. But, human toxocariasis was associated with high incidence of atopy and asthmatic symptoms (Despommier, 2003). Chan et al. (2001) reported that toxocariasis might increase possibility of allergic diseases, especially in children. Pinelli et al. (2008) reported that Toxocara infection in experimental models paved the way to allergic diseases, like asthma which is prevalent worldwide. A common immunological feature in allergic asthma and toxocariasis was the induction of a Th2 type of immune response characterized by high levels of total IgE and eosinophilia (Gonzalez et al, 2006). Atopy is a heritable predisposition to produce abnormal amount of IgE due to contact with aeroallergens. One could have typical manifestations of asthma, rhino-conjunctivitis or eczema (Johansson et al, 1968). Total $\operatorname{IgE}(\mathrm{t} \operatorname{IgE})$, allergen-specific $\operatorname{IgE}(\mathrm{s} \operatorname{IgE})$, and allergen skin prick test (SPT) are common diagnostic markers of atopic disease. They can differ considerably, with important diagnostic and epidemiological implications. SPT was the best efficient test diagnose current respiratory allergic diseases while tIgE gave a lower diagnostic value than SPT and/or sIgE (Johansson et al, 2004)

Significant relation between Toxocara spp. prevalence and increased levels of total and aeroallergen-specific $\operatorname{IgE}$ (sIgE), skin prick test reactivity (SPT), and asthma incidence were reported (Kanobana et al, 2013). But, no relation between anti-Toxocara spp. IgG antibodies and allergic markers was reported (Fernando et al, 2009). Mendonca et al. (2012) reported that Toxocara seropositivity was associated with decreased incidence of skin prick test reactivity to common aeroallergens that might act as a modifier in the relation between $\operatorname{SIgE}$ and SPT.
This study aimed to evaluate the effects of Toxocara infection on atopy and asthma, and relation between seroprevalence of anti Toxocara $\mathrm{IgG}$ and asthma

\section{Subjects and Methods}

This study was done on asthmatic bronchitis children in outpatient's clinics of Zagazig University Hospitals from $1^{\text {st }}$ January to $1^{\text {st }}$ October 2017. The sample consisted of two groups. G1: 118 children with confirmed asthmatic bronchitis from Pediatric Outpatient's Clinics. GII: 100 cross-matched children selected randomly from the hospitals visitors.

The patients aged between 4 and10 years from both sexes, with different socioeconomic and educational levels. An informed written consent was obtained from parents. Patients with other medical conditions or other parasitological disease, Also presence of one of asthma risk factors like that of; family history of asthma, exposure to cigarette smoke at home, presence of low birth weight as estimated from birth records or history of recurrent respiratory infections from childhood were recorded. Those exposed to pesticides was excluded. Current asthmatic patients were recorded after Asher and Weiland (1998). The second or the standard method was physician-diagnosed asthma (Kemp et al, 1996).

The sociodemographic data was assessed as age, sex, pet-animals, residence either urban or rural, outdoors playing, family status and mother's education.

Fecal sample was collected from each subject in a dry cartoon container. The feces were macroscopically examined for color, consistency, mucus and presence of worms or parts of them. Then, stained direct smears and formalin-ethyl acetate concentration flotation were examined microscopically by low and high powers to detect helminthic ova, larvae, trophozoites and cysts. Positive cases with parasites other than toxocariasis were excluded to avoid cross-reactions. Individually, five $\mathrm{ml}$ venous blood was collected in 2 tubes, one with anticoagulant for 
detection of eosinophilia corresponded to levels above $400 / \mathrm{mm}^{3}$ (Figueiredo et al, 2005). The second was centrifuged to separate sera which were stored at $-20^{\circ} \mathrm{C}$ until needed for anti-Toxocara IgG and total IgE

Immunological investigation: Sera were tested for anti-Toxocara IgG by Rida-Screen Toxocara-IgG ELISA kit (R-Biopharm AG, Germany) purified antigens coated to a micro-well plate. Serum antibodies was bind to antigens and detected by using enzymelabeled Protein A (conjugate) that converted colorless substrate $(\mathrm{H} 2 \mathrm{O} 2 / \mathrm{TMB})$ to a blue end product. Sulphuric acid stopped reaction and turned the mixture color to yellow. Measurement was at $450 \mathrm{~nm}$ on a photometer with a reference wave length $\geq 620 \mathrm{~nm}$.

Quantitative measurement of total IgE antibodies concentration was done by using ELISA kit (Immunospec corporation, CA), where levels higher than 200IU/ml were considered high.

Skin Prick test was performed using extracts of allergens used worldwide by ISAAC, as, house dust mite and cockroach (ALK Abello, Nieuwegein, The Nether- lands). Both have been reported as major atopic sensitizers in developing countries Histamine $(10 \mathrm{mg} / \mathrm{ml})$ and allergen diluent were used as positive and negative controls, respectively. Both extracts and controls were injected on the volar aspect of the left forearm using separate ALK lancets. Skin response was read after $15 \mathrm{~min}$, positive one detected as a wheal about $3 \mathrm{~mm}$ or larger of significant reaction without diluent control reactivity Atopy was defined as a positive SPT when positively reacted to at least one of the applied allergens. Those taking regular short acting antihistamines were asked to stop for at least $72 \mathrm{~h}$ prior to skin prick test.

Statistical analysis: SPSS version 19.0 was used to construct the database and analysis. Chi-square test and Odds Ratio (OR) differentiated between groups. Significant level oselected was $\mathrm{p}$ value $<0.05$.

\section{Results}

Among 118 asthmatic bronchitis patients $17 \%$ of subjects were seropositive for antiToxocara spp., and 7\% in 100 control subjects. All details were given in tables $(1,2,3$ \& 4).

Table 1: Sociodemographic and characteristic data of groups.

\begin{tabular}{|c|c|c|c|c|}
\hline Variable & & 118) & & \\
\hline & No. & $\%$ & No. & $\%$ \\
\hline Male & 67 & 57 & 57 & 57 \\
\hline Female & 51 & 43 & 43 & 43 \\
\hline Age in years $7-10$ & 66 & 56 & 62 & 62 \\
\hline $4-6$ & 52 & 44 & 38 & 38 \\
\hline Family income Low & 69 & 59 & 15 & 15 \\
\hline Moderate & 49 & 41 & 85 & 85 \\
\hline Residence & 78 & 66 & 44 & 44 \\
\hline Urban & 40 & 34 & 56 & 56 \\
\hline Education & 84 & 71 & 68 & 68 \\
\hline Ignorant & 34 & 29 & 32 & 32 \\
\hline Employment Employed & 66 & 56 & 30 & 30 \\
\hline Unemployed & 52 & 44 & 70 & 70 \\
\hline Pet contact & 48 & 41 & 40 & 40 \\
\hline No & 70 & 59 & 60 & 60 \\
\hline Soil contact & 34 & 29 & 30 & 30 \\
\hline No & 84 & 71 & 70 & 70 \\
\hline Toxocara $\operatorname{IgG}$ & 20 & 17 & 7 & 7 \\
\hline Negative & 98 & 83 & 93 & 93 \\
\hline eosinophilia & 34 & 29 & 25 & 25 \\
\hline$>4$ & 84 & 71 & 75 & 75 \\
\hline Skin prick test Negative & 86 & 73 & 85 & 85 \\
\hline Positive & 32 & 27 & 15 & 15 \\
\hline$<0.2 \mathrm{mg} / \mathrm{ml}$ & 41 & 35 & 93 & 93 \\
\hline$\geq 0.2 \mathrm{mg} / \mathrm{ml}$ & 77 & 65 & 7 & 7 \\
\hline
\end{tabular}


Table 2: Comparison of anti-Toxocara spp. IgG Sociodemographic data between asthmatic patients

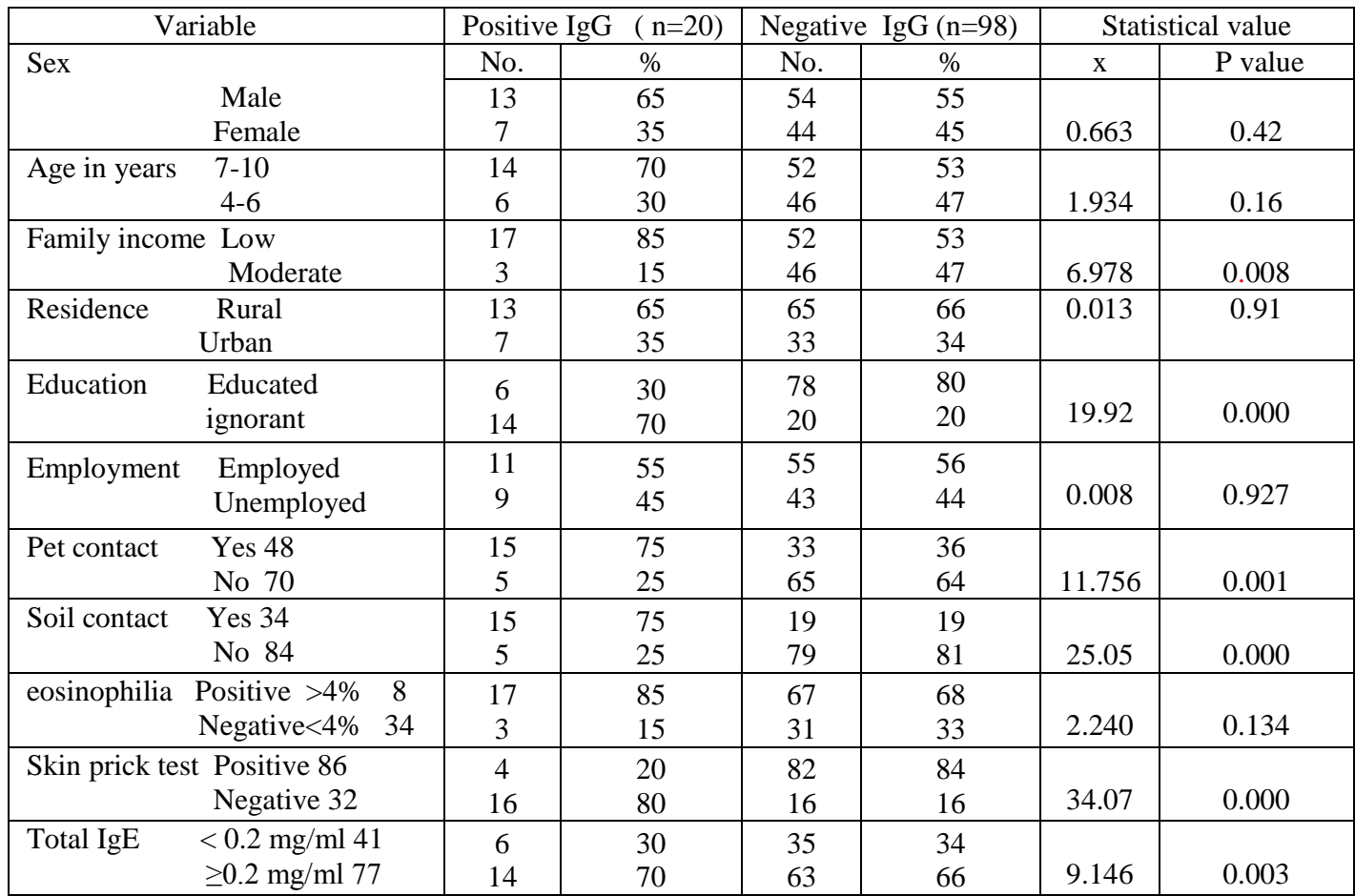

Table 3: Comparison of Anti-Toxocara spp. IgG data between controls

\begin{tabular}{|c|c|c|c|c|c|c|}
\hline Variable & Positi & $(n=7)$ & Negat & $(\mathrm{n}=93$ & Statis & al value \\
\hline Sex & No. & $\%$ & No. & $\%$ & $\mathrm{x}$ & P. value \\
\hline Male & 6 & 86 & 51 & 55 & & \\
\hline Female & 1 & 14 & 42 & 45 & 2.532 & 0.111 \\
\hline $\begin{array}{lr}\text { Age in years } & 7-10 \\
& 4-6 \\
\end{array}$ & $\begin{array}{l}5 \\
2 \\
\end{array}$ & $\begin{array}{l}71 \\
29 \\
\end{array}$ & $\begin{array}{l}57 \\
36 \\
\end{array}$ & $\begin{array}{l}61 \\
39 \\
\end{array}$ & 0.284 & 0.594 \\
\hline $\begin{array}{r}\text { Family income } \begin{array}{c}\text { Low } \\
\text { Moderate }\end{array}\end{array}$ & $\begin{array}{l}2 \\
5\end{array}$ & $\begin{array}{l}29 \\
71\end{array}$ & $\begin{array}{l}13 \\
80\end{array}$ & $\begin{array}{l}14 \\
86\end{array}$ & 2.035 & 0.126 \\
\hline $\begin{array}{ll}\text { Residence } & \text { Rural } \\
& \text { Urban } \\
\end{array}$ & $\begin{array}{l}6 \\
1 \\
\end{array}$ & $\begin{array}{l}86 \\
14\end{array}$ & $\begin{array}{l}38 \\
55\end{array}$ & $\begin{array}{l}41 \\
59\end{array}$ & 5.032 & 0.020 \\
\hline $\begin{array}{rr}\text { Education } & \text { Educated } \\
& \text { Ignorant } \\
\end{array}$ & $\begin{array}{l}6 \\
1\end{array}$ & $\begin{array}{l}86 \\
14\end{array}$ & $\begin{array}{l}62 \\
31\end{array}$ & $\begin{array}{l}67 \\
33\end{array}$ & 1.085 & 0.297 \\
\hline $\begin{array}{l}\text { Employment Employed } \\
\text { Unemployed }\end{array}$ & $\begin{array}{l}2 \\
5\end{array}$ & $\begin{array}{l}29 \\
71\end{array}$ & $\begin{array}{l}28 \\
65\end{array}$ & $\begin{array}{l}31 \\
69\end{array}$ & 0.007 & 0.921 \\
\hline $\begin{array}{lll}\text { Pet contact } & \text { Yes } & 40 \\
& \text { No } & 60 \\
\end{array}$ & $\begin{array}{l}5 \\
2 \\
\end{array}$ & $\begin{array}{l}71 \\
29 \\
\end{array}$ & $\begin{array}{l}35 \\
58 \\
\end{array}$ & $\begin{array}{l}38 \\
62 \\
\end{array}$ & 3.097 & 0.078 \\
\hline $\begin{array}{r}\text { Soil contact Yes } 30 \\
\text { No } 70 \\
\end{array}$ & $\begin{array}{l}4 \\
3 \\
\end{array}$ & $\begin{array}{l}57 \\
43 \\
\end{array}$ & $\begin{array}{l}26 \\
67 \\
\end{array}$ & $\begin{array}{l}28 \\
72 \\
\end{array}$ & 2.641 & 0.104 \\
\hline $\begin{array}{rrr}\text { eosinophilia } & >4 \% & 25 \\
& <4 \% & 75 \\
\end{array}$ & $\begin{array}{l}6 \\
1\end{array}$ & $\begin{array}{l}86 \\
14\end{array}$ & $\begin{array}{l}19 \\
74\end{array}$ & $\begin{array}{l}20 \\
80\end{array}$ & 14.86 & 0.000 \\
\hline $\begin{array}{r}\text { Skin prick test Positive } 85 \\
\text { Negative } 15\end{array}$ & $\begin{array}{l}2 \\
5\end{array}$ & $\begin{array}{l}29 \\
71 \\
\end{array}$ & $\begin{array}{l}83 \\
10 \\
\end{array}$ & $\begin{array}{l}89 \\
11 \\
\end{array}$ & 18.80 & 0.000 \\
\hline $\begin{aligned} \text { Total IgE } & <0.2 \mathrm{mg} / \mathrm{ml} 93 \\
& \geq 0.2 \mathrm{mg} / \mathrm{ml} \quad 7\end{aligned}$ & $\begin{array}{l}1 \\
6\end{array}$ & $\begin{array}{l}14 \\
86\end{array}$ & $\begin{array}{c}92 \\
1\end{array}$ & $\begin{array}{c}99 \\
1\end{array}$ & 71.64 & 0.000 \\
\hline
\end{tabular}

Table 4: Seroprevalence between Patients and Control Group

\begin{tabular}{|c|c|c|c|c|c|c|}
\hline \multirow[t]{2}{*}{ Variable } & \multicolumn{2}{|c|}{ Positive IgG } & $\mathrm{Neg}$ & $\mathrm{IgG}$ & \multirow[t]{2}{*}{ X Score } & \multirow[t]{2}{*}{$\mathrm{P}$ value } \\
\hline & No. & $\%$ & No. & $\%$ & & \\
\hline Patients group & 20 & 17 & 98 & 83 & \multirow[t]{2}{*}{4.938} & \multirow[t]{2}{*}{0.026} \\
\hline Control group & 7 & 7 & 93 & 93 & & \\
\hline
\end{tabular}




\section{Discussion}

In Egypt, zoonotic toxocariasis as one of the widely distributed geoparasites was reported (Khalil, 1977; Morsy et al, 1981; Nada et al, 1996; Antonios et al, 2008; Haridy et al, 2009; El-Tras et al, 2011: Etewa et al, 2014). Generally speaking, asthma increased in the industrialized countries (Eder et al, 2006). Incidence of asthma was $20.8 \%$ corresponded to those recorded in Latin American countries and in some developed countries worldwide (Mallol et al, 2000; Pitrez and Stein, 2008 Vereecken et al, 2012).

Almost $21 \%$ of the population was infected with one or more intestinal helminthes. Geohelminthes infection was considered as a potential risk factor for asthma (Cooper 2004; VanRiet et al, 2007). The association between asthma and toxocariasis has not been well documented. But, there were some studies showing positive association in human (Buijs et al, 1997; Ferreira et al, 2007) and in animal model (Pinelli et al, 2008), but shown no relation was reported (Sharghi et al, 2001).

In the present study, the IgG positive children were $17 \%$ \& $10 \%$ among asthmatic patients and controls respectively. But, Fernando et al. (2009) in Sri Lanka reported $29 \%$ of toxocariasis in hospitalized children with bronchial asthma recorded. Mendonca et al. (2013) in Brazil reported high rates of toxocariasis $(63.6 \%)$ in elementary school children in urban and semi-rural areas. Also, Kanobana et al. (2013) reported that antibodies of Toxocara spp. in $40.1 \%$ of the children. Nyan et al. (2001) in Banjul reported that toxocariasis was more common in urban $17 \%$ versus $8.2 \%$ rural one. Mendona et al. (2013) in Salvador found that $48.4 \%$ of children aged $4-11$ years in urban suffered from helminthic infections.

The present study found no significant difference between toxocariasis and family income. But, Souza et al. (2011) in Salvador recorded a positivity rate of $59.9 \%$ with a higher incidence among lower social classes. Also, Alvarado-Esquivel (2013) reported that socioeconomic status was an important factor in positive rate of toxocariasis. However, Silva et al. (2016) did not accept such an effect using family income and maternal schooling as a monitor for social classes.

The present study found highly significant difference between toxocariasis and pet contact. Many studies suggested that dog contact was the main risk factor of T. canis, as a direct source of infection, but cat exposure was less frequently as the cats cover feces under sand (Loukas et al, 2000; Schnieder et al, 2011; Strube et al, 2013).

In the present study, there was a significant relation between toxocariasis and soil contract. Buijs et al. (1994), Kerr-Muir et al, (1994) and El Tantawey et al. (2013) found that eating soil (pica) was a risk factor for infection. In the present study, there was no significant difference between toxocariasis and sexes. Nyan et al. (2001) in Banjul reported no significant difference among sexes regarding intestinal helminthic infections. However, Silva et al. (2016) found a twofold increase in risk of toxocariasis in boys compared to girls. This might be due to the fact that boys always plays outdoors (Roldán et al, 2010), and more exposure to contaminated environments (Wi'sniewska-Ligier et al, 2012; Romero Núnez et al, 2013).

In the present study, there was highly significant difference between toxocariasis and mother ignorance. This made the ignorant mother had no knowledge about primary the hygienic items (Kanobana et al, 2013).

The present study showed no significant difference between toxocariasis and eosinophilia level in asthmatic patients, but a highly significant difference between Toxocara spp. Infection and eosinophilia among controls. Mendonca et al. (2013) reported that eosinophilia was $4 \%$ more in students positive for anti-Toxocara spp. than in controls. Dattoli et al. (2011) recorded higher of eosinophils levels in pure toxocariasis patients. Martin et al. (2008) reported that $87 \%$ of toxocariasis patients had elevated eosinophilia. Fernando et al. (2009) reported sig- 
nificant higher eosinophilia in non-asthmatic toxocariasis children.. In the present study there was significant relation between Toxocara spositivity and total IgE positivity. This agreed with the results of Mendonca et al. (2012) and El-Tantawey et al. (2013).

Alcântara-Neves et al. (2014) found strong positive association between helminthiasis and both total $\mathrm{IgE}$ and eosinophilia. Saporito et al. (2008) and Bahnea et al. (2008) reported that eosinophilia and high IgE level in asthmatic patients suggested toxocariasis. The present study, found significant negative relation between toxocariasis seropositivity and skin prick test. This went with with the reports of Mendonca et al. (2012) and Silva et al. (2016).

The present study showed high significant relation between Toxocara spp. and asthma, which agreed with others (Buijs et al, 1997; Kanobana et al, 2013; El Tantawey et al, 2013). Ferreira et al. (2007) found that $21.5 \%$ children had Toxocara antibodies and independent association between asthma and positivity But, Sharghi et al. (2001) and Taylor (1993) did not find relation between toxocariasis and asthma.

\section{Conclusion}

The outcome data showed Toxocara positivity was associated with pets contact and/or soil contact, and low family income and ignorant mothers. No association was between Toxocara spp. rate and blood eosinophilia level in asthmatic patients. There was highly significant association between toxocariasis and eosinophilia among controls. Significant prevalence of anti Toxocara IgG in asthmatic patient also significant relation between toxocariasis and total IgE while significant negative relation between toxocariasis and skin prick test

\section{References}

Alcântara-Neves, NM, Britto, G, Veiga, RV, Figueiredo, CA, Fiaccone, RL, et al, 2014: Effects of helminth co-infections on atopy, asthma andcytokine production in children living in a poor urban area in Latin America. BMC Res. Notes 7, 8:17-24.
Alvarado-Esquivel, C, 2013: Toxocariasis in waste pickers: A case control seroprevalence study. PLoS One 8, e54897

Antonios, SN, Eid, MM, Khalifa, EA, Othman, AA, 2008: Seroprevalence study of Toxocara canis in selected Egyptian patients. J. Egypt. Soc. Parasitol. 38, 1:313-8.

Araujo, MI, Lopes, AA, Medeiros, M, Cruz, AA, Sousa-Atta, L, et al, 2000: Inverse association between skin response to aeroallergens and Schistosoma mansoni infection. Int. Arch. Allergy Immunol. 123:145-8.

Asher, MI, Weiland, SK, 1998: The International Study of Asthma and Allergies in Childhood (ISAAC) Steering Committee. Clin. Exp. Allergy 28, 5:S52-66.

Bahnea, RG, Ivan, A, Cârdei, E, Luca, MC, Stoica, O, 2008: Retrospective clinical and laboratory study of the toxocariasis cases hospitalized between 2005 and 2008. Rev. Med. Chir. Soc. Med. Nat. Iasi. 112:938-41

Bowman, DG, Hendrix, DS, 2008: Feline Clinical Parasitology, $1^{\text {st }}$ ed. Iowa State University Press A Blachwell Science Company $(281,286)$.

Buijs, J, Borsboom, G, van Gemund, JJ, Hazebroek, A, van Dongen, PA, 1994: Toxocara seroprevalence in 5-year-old elementary schoolchildren: Relation with allergic asthma. Am. J. Epidemiol. 140:839-47.

Buijs, J, Borsboom, G, Renting, M, Hilgersom, WJ, van Wieringen, JC, et al, 1997: Relationship between allergic manifestations and Toxocara seropositivity: a cross-sectional study among elementary school children. Eur. Respir. J. 10:1467-75

Buijs, J, Egbers, MW, Nijkamp, FP, 1995: Toxocara canis-induced airway eosinophilia and tracheal hyporeactivity in guinea pigs and mice. Euro. J. Pharmacol. 293:207-15.

Carvalho, E, Rocha, R, 2011: Toxocariasis: visceral larva migrans in children. J. Pediatr. (Rio J.) 87:100-10.

Chan, PW, Anuar, AK, Fong, MY, Debruyne, JA, Ibrahim, J, 2001: Toxocara seroprevalence and childhood asthma among Malaysian children. Pediatr. Int. 43:350-3.

Cooper, PJ, 2004: Intestinal worms and human allergy. Parasite Immunol.; 26: 455-467

Cooper, PJ, 2008: Toxocara canis infection: an important and neglected environmental risk factor for asthma? Clin. Exp. Allergy 38:551-3. Dagoye, D, Bekele, Z, Woldemichael, K, Nida, 
H, Yimam M, et al, 2003: Wheezing, allergy, and parasite infection in children in urban and rural Ethiopia. Am. J. Respir. Crit. Care Med. 167:1369-73.

Dattoli, VCC, Freire, SM, Mendonca, LR, Santos, PC, Meyer, R, A et al, 2011: Toxocara canis infection is associated with eosinophilia and total IgE. Trop. Med. Int. Hlth. 16:514-7.

Despommier, D, 2003: Toxocariasis: clinical aspects, epidemiology, medical ecology and molecular aspects. Clin. Microbiol. Rev. 16:265-72. Eder, W, Ege, MJ, von Mutius, E, 2006: The asthma epidemic. N. Engl. J. Med. 355:2226-35

El-Tantawy, NL, El-Nahas, HA, El-Assmy, M M, Alsalem, AM, 201): Clinico-sero-epidemiological evaluation of toxocariasis in asthmatic pediatric children in Mansoura city in Egypt.

Arch. Clin. Microbiol. 4, 4:3-8.

El-Tras, WF, Holt, HR, Tayel, AA, 2011: Risk of Toxocara canis eggs in stray and domestic dog hair in Egypt. Vet. Parasitol. 178, 3/4:31923

Etewa, SE, Abdel-Rahman, SA, Abd El-Aal, NF, Fathy, GM, El-Shafey, MA, et al, 2014: Geohelminths distribution as affected by soil properties, physicochemical factors and climate in Sharkyia Governorate, Egypt. J. Parasit. Dis. 10.1007/s12639-014-053

Fernando, D, Wickramasinghe, P, Kapilanand, G, Dewasurendra, RL, Amarasooriya, M, Dayaratne, A, 2009: Toxocara seropositivity in Sri Lankan children with asthma. Pediatr. Int. 51:241-5

Ferreira, MU, Rubinsky-Elefant, G, de Castro, T, Hoffmann, EH, da Silva, M. et al, 2007: Bottle feeding and exposure to Toxocara as risk factors for wheezing illness among under-five Amazonian children: A population based crosssectional study. J. Trop. Pediatr. 53:119-24.

Figueiredo, SD, Taddei, JA, Menezes, JJ, Novo, NF, Silva, EO, et al, 2005: Clinical-epidemiological study of toxocariasis in a pediatric population. J. Pediatr. 81:126-32

Fragoso, RP, Monteiro, MB, Lemos, EM, Pereira FE, 2011: Anti-Toxocara antibodies detected in children attending elementary school in Vitoria, State of Espírito Santo, Brazil: prevalence and associated factors. Rev. Soc. Bras. Med. Trop. 44:461-6.

Gavignet, B, Piarroux, R, Aubin, F, Millon, L, Humbert, P, 2008: Cutaneous manifestations of human toxocariasis. J. Am. Acad. Dermatol. 59:1031-42.
Gonzalez-Quintela, A, Gude, F, Campos, J, Garea, MT, Romero, PA, et al, 2006: Toxocara infection seroprevalence and its relationship with atopic features in a general adult population. Int. Arch. Allergy Immunol. 139:317-24

Hotez, PJ, Wilkins, PP, 2009: Toxocariasis: America's most common neglectedinfection of poverty and a helminthiasis of global importance? PLoS Negl. Trop. Dis. 3:e400

Johansson, SGO, Mellbin, T, Vahlquist, B, 1968: Immunoglobin levels in Ethiopian preschool children with special reference to high concentrations of IgE (IgND). Lancet 1:1118-21.

Johansson, S, Bieber, T, Dahl, R, et al, 2004: Revised nomenclature for allergy for global use: Report of the Nomenclature Review Committee of the World Allergy Organization, October 2003. J. Allergy Clin. Immunol. 113:832-6.

Haridy, FM, Hassan, AA, Hafe, AO, El-Sherbini, GT, Morsy, TA, 2009: External and intestinal parasites of pet dogs with reference to zoonotic toxocariasis. J. Egypt. Soc. Parasitol. 39, 1:321-6.

Kanobana, K, Vereecken, K, Diaz, R, Sariego, I, Rojas, L, et al, 2013: Toxocara seropositivity, atopy and asthma: a study in Cuban schoolchildren. Trop. Med. Int. Hlth. 18: 403-6.

Kemp, T, Pearce, N, Crane, J, Beasley, R, 1996: Problems of measuring asthma prevalence. Respirology 1:183-8.

Kerr-Muir, MG, 1994: Toxocara canis and human health. BMJ. 309:5-6.

Khalil, HM, 1977: Toxocariasis in Egypt. J. Egypt. Publ. Hlth. Assoc. 52, 5:330-43

Loukas, A, Hintz, M, Linder, D, Mullin, NP, Parkinson, J, et al, 2000: A family of secreted mucins from the parasitic nematode Toxocara canis bears diverse mucin domains but shares similar flanking six-cysteine repeat motifs. J. Biol. Chem. 275:39600-7

Macpherson, CN, 2013: The epidemiology and public health importance of toxocariasis: a zoonosis of global importance. Int. J. Parasitol. 43: 999-1008

Magnaval, JF, Glickman, LT, Dorchies, P, Morassin, B, 2001: Highlights of human toxocariasis. Korean J. Parasitol. 39:1-11

Maizels, RM, 2013: Toxocara canis: molecular basis of immune recognition and evasion. Vet. Parasitol. 193, 4:365-74.

Mallol, J, Sole, D, Asher, I, et al, 2000: Prevalence of asthma symptoms in Latin America: Int- 
ernational Study of Asthma and Allergies in Childhood (ISAAC). Pediatr. Pulmonol. 30:439-44. Martin, UO, Machuca, PB, Demonte, MA, Contini, L, 2008: Analysis of children with a presumptive diagnosis of toxocariasis in Santa Fe, Argentina. Med. (B Aires) 68:353-7

Mendonca, LR, Veiga, RV, Dattoli, VC, Figueiredo, CA, Fiaccone, R, et al, 2012: Toxocara seropositivity, atopy and wheezing inchildren living in poor neighborhoods in urban Latin American. PLoS Negl.Trop. Dis. 6:e1886.

Mendonca, LR, Figueiredo, CA, Esquivel, R, Fiaccone, RL, Carvalho, L, et al, 2013: Seroprevalence and risk factors for Toxocara infection in children from an urban large setting in Northeast Brazil. Acta Trop. 128, 90-95

Moncayo, A, Vaca, M, Oviedo, G, Erazo, S, Quinzo, I, et al, 2010: Risk factors for atopic and non-atopic asthma in a rural area of Ecuador. Thorax 65:409-16.

Morsy, TA, Sadek, MS, Abdel Hamid, MY, 1981: Intestinal parasites of stray cats in Cairo, Egypt. J. Egypt. Soc. Parasitol. 11, 2:331-45.

Nada, SM, Abazza, BE, Mahmoud, LA, Habeeb, YS, Hussein, HF, et al, 1996: Toxocariasis as a cause of renal disease in children in Sharkia Governorate, Egypt. J. Egypt. Soc. Parasitol. 26, 3:709-17.

Nyan, OA, Walraven, GE, Banya, WA, et al, 2001: Atopy, intestinal helminth infection and total serum IgE in rural and urban adult Gambian communities. Clin. Exp. Allergy 31:1672-8.

Pinelli, E, Brandes, S, Dormans, J, Gremmer, E, van Loveren, H, 2008: Infection with the roundworm Toxocara canis leads to exacerbation of experimental allergic airway inflammation. Clin. Exp. Aller. 38:649-58.

Pitrez, PM, Stein, RT, 2008: Asthma in Latin America: the dawn of a new epidemic. Curr. Opin. Aller. Clin. Immunol. 8:378-83.

Roldán, WH, Cavero, YA, Espinoza, YA, Jiménez, S, Gutiérrez, CA, 2010: Human toxocariasis: A sero-epidemiological survey in the Amazonian City of Yurimaguas, Peru. Rev. Inst. Med. Trop. Sao Paulo 52, 1:37-42.

Romero Nú nez, C, Mendoza, GD, Yãnez, S, Ponce, M, Bustamante, P, et al, 2013: Prevalence and risk factors associated with Toxocara canis infection in children. Sci. World J. 5:72-89 Saporito, L, Scarlata, F, Colomba, C, Infurnari, L, Giordano, S, et al, 2008: Human toxocariasis: A report of nine cases. Acta Paediatr. 97: 1301-2.
Schnieder, T, Laabs, EM, Welz, C, 2011: Larval development of Toxocara canis in dogs. Vet. Parasitol. 175:193-206.

Sharghi, N, Schantz, PM, Caramico, L, Ballas, K, Teague, BA, et al, 2001: Environmental exposure to Toxocara as a possible risk factor for asthma: A clinic-based case-control study. Clin. Infect. Dis. 32:111-6.

Silva, MB, Amor, AL, Santos, LN, Galvão, A A, OviedoVera, AV, et al, 2016: Risk factors for Toxocara spp. seroprevalence and its association with atopy $\&$ asthma phenotypes in school age children in a small town and semi-rural areas of Northeast Brazil. Acta Trop. 17, 9:425-8.

Souza, RF, Dattoli, VC, Mendonca, LR, Jesus, JR, Baqueiro, T, et al, 2011: Prevalence and risk factors of human infection by Toxocara canis in Salvador, State of Bahia, Brazil. Rev. Soc. Bras. Med. Trop. 44:516-9.

Strube, C, Heuer, L, Janecek, E, 2013: Toxocara spp. infections in paratenic hosts. Vet. Parasitol. 193:375-89.

Taylor, MRH, 1993: Toxocariasis in Ireland. In: Toxocara and Toxocariasis: Lewis, JW, Maizels, RM, eds.; London Institute of Biology and the British Society for Parasitology, London.

Tschopp, JM, Sistek, D, Schindler, C, et al, 1998: Current allergic asthma and rhinitis: diagnostic efficiency of three commonly used atopic markers (IgE, skin prick tests, and Phadiatop). Results from 8329 randomized adults from the SAPALDIA Study. Swiss study on air pollution and lung diseases in adults. Allergy 53:608-13.

Van Riet, E, Hartgers, FC, Yazdanbakhsh, M, 2007: Chronic helminth infections induce immunomodulation: consequences and mechanisms. Immunobiol. 212:475-90

Vereecken, K, Kanobana, K, Wordemann, M, et al, 2012: Associations between atopic markers in asthma and intestinal helminth infections in Cuban schoolchildren. Pediat. Aller. Immunol. 23:332-8

Walsh, MG, Haseeb, MA, 2012: Reduced cognitive function in children with toxocariasis in a nationally representative sample of the United States. Int. J. Parasitol. 42, 13/14:1159-63.

Wi'sniewska-Ligier, M, Wo'zniakowska-Gesicka, T, Sobolewska, J, Markiewicz-Jó’zwi ak, A, Wieczorek, M, 2012: Analysis of the co-urse and treatment of toxocariasis in children-a longterm observation. Parasitol. Res. 110:2363- 71. 